(C) Entomologica Fennica. 10 July 2019

\title{
Coleophora sirella Tabell \& Mutanen, sp. n. from Finland (Lepidoptera: Coleophoridae)
}

\author{
Jukka Tabell, Marko Mutanen \& Reijo Siloaho
}

Tabell, J., Mutanen, M. \& Siloaho, R. 2019: Coleophora sirella Tabell \& Mutanen, sp. n. from Finland (Lepidoptera: Coleophoridae). — Entomol. Fennica 30: 49-56. https://doi.org/10.33338/ef.82918

Coleophora sirella Tabell \& Mutanen, sp. n. from Finland is described as new. The species resembles most closely $C$. glitzella O. Hofmann, 1869, C. murinella Tengström, 1848 and C. juncicolella Stainton, 1851 but has diagnostic differences in its life history, external appearance, genital morphology as well as DNA barcode. The new species feeds on Empetrum nigrum L. Adult male and female, their genitalia as well as larval case are illustrated, and the known distribution range is given. DNA barcodes are provided for the new species and its closest European relatives.

J. Tabell, Laaksotie 28, FI-19600 Hartola, Finland; E-mail: jukka.tabell @phnet.fi

M. Mutanen, Department of Ecology and Genetics, PO Box 3000, 90014 University of Oulu, Finland. E-mail: marko.mutanen@oulu.fi

R. Siloaho, Marjakorinkuja 1, FI-51200 Kangasniemi, Finland. E-mail: reijo. siloaho@pp.inet.fi

Received 3 June 2014, accepted 25 May 2018

\section{Introduction}

The species of Coleophora Hübner, 1822 occurring on various peatlands in Northern Europe have been well known for many decades. Since the descriptions of C. plumbella Kanerva, 1941 and C. obscuripalpella Kanerva, 1941, only one such species has been discovered. This species is C. thulea Johansson, 1967, which inhabits different kinds of subalpine bogs. Quite surprisingly, in 2006, the Finnish amateur lepidopterist Reijo Siloaho collected a series of a tiny coleophorid moth from a small bog in central Finland. The moths did not match externally any known Fennoscandian species. The examination of genitalia and the comparison of available DNA barcodes of Palaearctic and Nearctic Coleophora species revealed that the specimens represent a previously unknown species. Later, careful examinations on the collection site showed that the new species feeds on Empetrum nigrum L. (Ericaceae), a plant that has not been recorded as a food plant for any previously described species of Coleophora. The new species is described in the present paper as Coleophora sirella Tabell \& Mutanen, sp. n.

\section{Materials and methods}

A great majority of the specimens of the new species has been collected at dawn by netting flying male adults in early morning sunshine. Most females have been captured by sweeping Empetrum nigrum and Calluna vulgaris (L.) Hull (Ericaceae) in the afternoon. A few specimens 
have also been collected at sunset by netting vegetation. One male specimen was reared from a larva.

For morphological studies of the genitalia, nine genitalia preparations were made by JT and RS (see the type material), following standard techniques (Robinson 1976). The genitalia were severed from the abdomen, and male genitalia spread out with two insect pins. After replacing the water with alcohol, the genitalia were mounted on a slide with Euparal fixative, and covered with a cover glass. The female genitalia were mounted ventral side upwards.

The photos of adult specimens and larval case were taken with Canon EOS 40D, Canon Macro Lens EF 100 mm 1:2.8 USM and Soligor Extension Tubes. The genitalia were photographed from the genitalia slides in ventral view with Leica DM 1000 Microscope and integrated Leica DF 295 digital camera. All final photos were combined of several layers of different depth of focus using CombineZP and edited with Adobe Photoshop CS4.

Five specimens were subjected to sequencing of a standard animal DNA barcode region (658 bp fragment of COI gene).

One leg of five specimens was deposited in microplate wells with $30 \mu \mathrm{L}$ of absolute alcohol in each well. These samples were sent to the Canadian Centre for DNA Barcoding (CCDB), Guelph, Canada, for DNA extraction, barcode amplification and sequence analysis. The laboratory protocols used are explained in deWaard et al. (2008). All five specimens were successfully sequenced, resulting in a full-length barcode fragment for three specimens and sequences of $640 \mathrm{bp}$ and $623 \mathrm{bp}$ for the remaining two specimens. Distance statistics were calculated using BOLD (Barcode of Life Data Systems) tools, accessible at http://www.boldsystems.org. To assess the phylogenetic position of $C$. sirella $\mathbf{s p .} \mathbf{n}$., a maximum likelihood tree including $C$. sirella sp. n. and 22 related species (142 specimens) of North European Coleophora was constructed with Mega 7 (Kumar et al. 2016). Node bootstrap supports were assessed with 500 bootstrap replications. Details of successfully sequenced voucher specimens, including voucher data, images and GenBank accession numbers, are publicly available through the dataset DS-COLSIR at

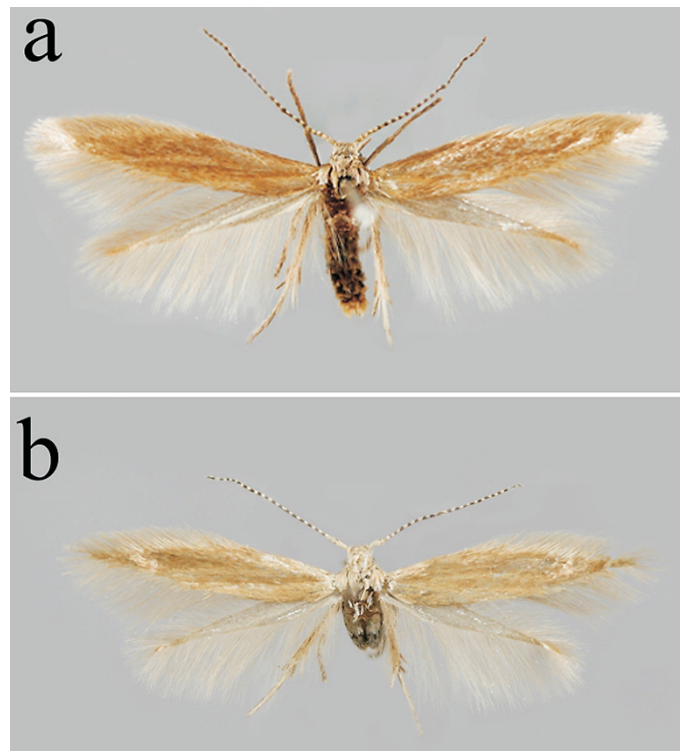

Fig. 1. Adults of Coleophora sirella sp. n. - a. Male. $-b$. Female.

www.boldsystems.org and at doi: dx.doi.org/ 10.5883/DS-COLSIR.

The type specimens are deposited in the collection of the Finnish Museum of Natural History, University of Helsinki, Finland (MZH) and the private collections of several collectors.

\section{Description of Coleophora sirella Tabell \& Mutanen, sp. n.}

Type material. Holotype $\widehat{\jmath}$ (GP 4739 J. Tabell): Finland, ES: Kangasniemi, YKJ 687:348, 5.VI.2006, R. Siloaho leg., coll. MZH.

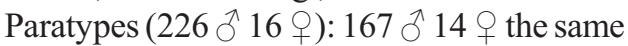
locality as in the holotype, but other collecting details as follows: 5.VI.2006 14 ^ (G.p. no. 46 R. Siloaho, Gen. prep. no. 27/2006 R. Siloaho), 6.VI.2006 3 ふૈ, 8.VI.2006 5 ふૈ, 9.VI.2006 2 ふ,, 10.VI.2006 2 ๙े, 12.VI.2006 1 ๙े, 15.VI.2006 3

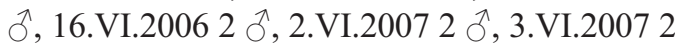
ふ, 4.VI.2007 10 ๙ 1 ㅇ (G.p. no. 77 R. Siloaho), 5.VI.2007 7 ๙ 2 ㅇ (GP 4679 J. Tabell), 6.VI.2007 4 đิ 2 ㅇ (GP 4731 J. Tabell, DNA sample 16581 Lepid Phyl), 8.VI.2007 4 (GP 4053 J. Tabell), 9.VI.2007 1 , 4.VI.2008 2 ô, 5.VI.2008 8 ๙ 1 ㅇ, 1.VI.2010 1 ふ, 15.VI.2010 17 ๙ (DNA sample 16591 Lepid Phyl),

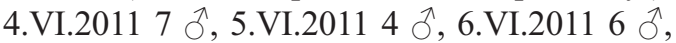




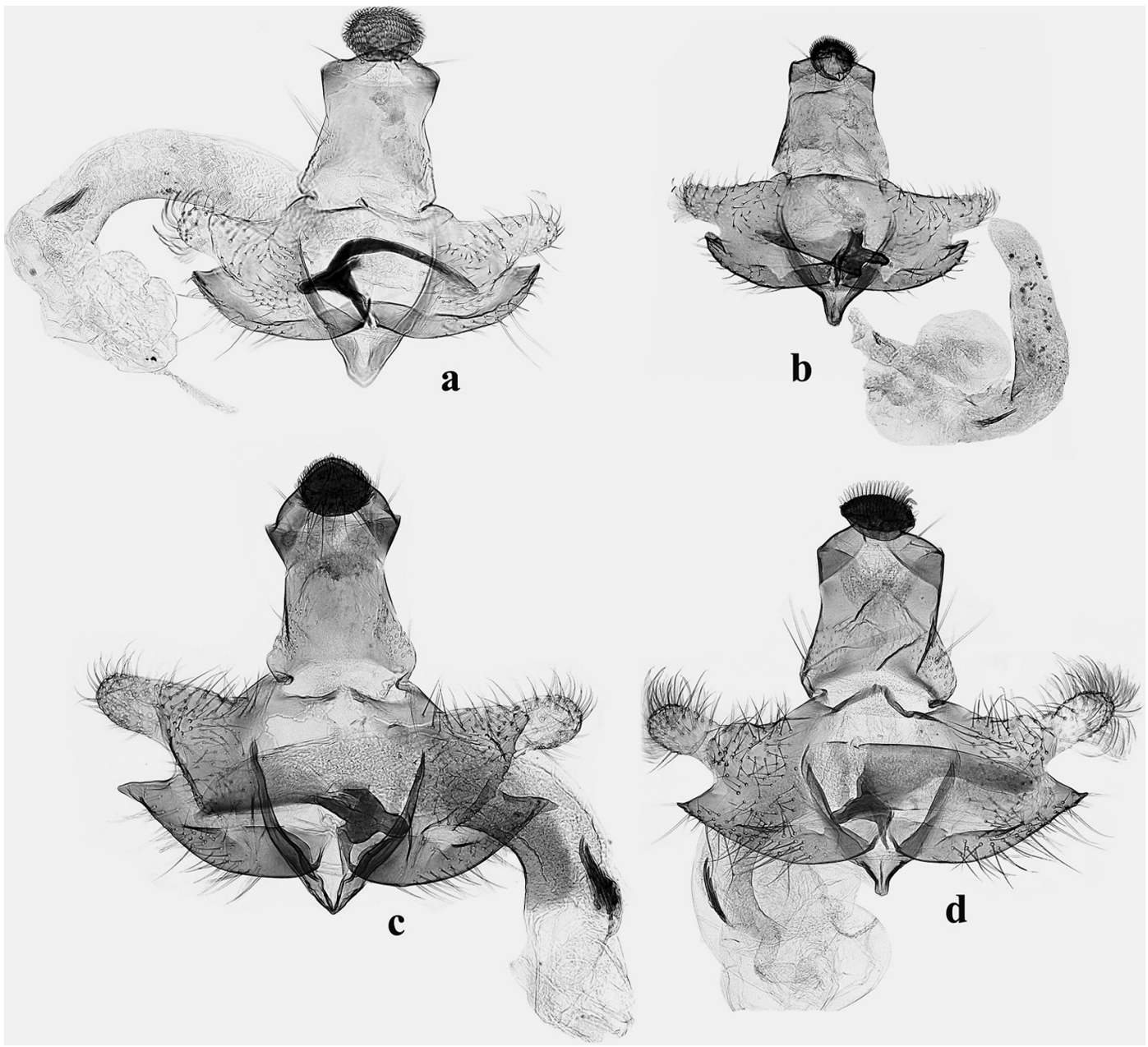

Fig. 2. Male genitalia of four related species of Coleophora. - a. Coleophora sirella sp. n., holotype (GP $4739 \mathrm{~J}$. Tabell). - b. Coleophora juncicolella, Finland, Kangasala (GP 4019 J. Tabell). - c. Coleophora murinella, Finland, Hartola (GP 1529 J. Tabell). - d. Coleophora glitzella, Finland, Hartola (GP 4496 J. Tabell).

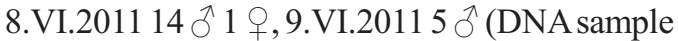
05627 Lepid Phyl), 10.VI.2011 9 Oे, all in colls Siloaho \& Tabell, 5.VI.2007 2 $\hat{\sigma}$ T. \& K. Nupponen leg. \& coll, 6.VI.2007 14 స T. \& K. Nupponen leg. \& coll., 6.VI.2007 3 ^ E. Saarela leg. \& coll., 6.VI.2007 10 ふै L. Sippola leg. \& coll., 7.VI.2007 4 § J. Tabell leg. \& coll., 8.VI.2007 2 \& J. Junnilainen leg. \& coll., 10.VI.2007 3 ₹ J. Junnilainen leg. \& coll., e.1. 20071 ऽ L. Sippola leg. \& coll.; Finland, ES: Joutsa, YKJ 684:45, 9.VI.2007 1 ठै 1 क J. Junnilainen leg. \& coll.; 9.VI.2009 1 § J.-P. Kaitila leg. \& coll.; Finland, ES: Eteläinen Haukkasuo, YKJ 674:349, 13.VI.2012 6 ठ J. Junnilainen leg. \& coll.; Finland, EK:
Vehkaojansuo, YKJ 672:349, 9.VI.2012 14 ๙ J. Junnilainen leg. \& coll.; Finland, EH: Hartola, YKJ 682:344, 5.VI.2008 1 ô, 9.VI.2009 5 ふૈ, 6.VI.2011 at 5.40-6.20 am $13 \AA$ (DNA sample 16587 Lepid Phyl), 9.VI.2012 at 6.303 J J. Tabell leg. \& coll.; Finland, PS: Rautavaara, YKJ 705:355, 20.VI.2013 4 § J. Junnilainen leg. \& coll.; Finland, $P P p$ : Tervola, 26.VI.1976 1 ๙ J. Jalava leg., coll. MZH; Finland, $P P p$ : Tornio, YKJ 731:38, 7.VII.1987 1 \& (G.p. no 66/2007 RS) E. Laasonen leg., coll. E. \& L. Laasonen; Finland, EP: Isojoki, YKJ 689:22, Iso Rapaneva, 13.VI.2009 6 ภ (GP 4740 J. Tabell) T. RintaPaavola leg. \& coll.; Finland, EP: Kurikka, YKJ 696:25, Kalistanneva, 10.VI.2010 2 $\widehat{~}$ T. Rinta- 


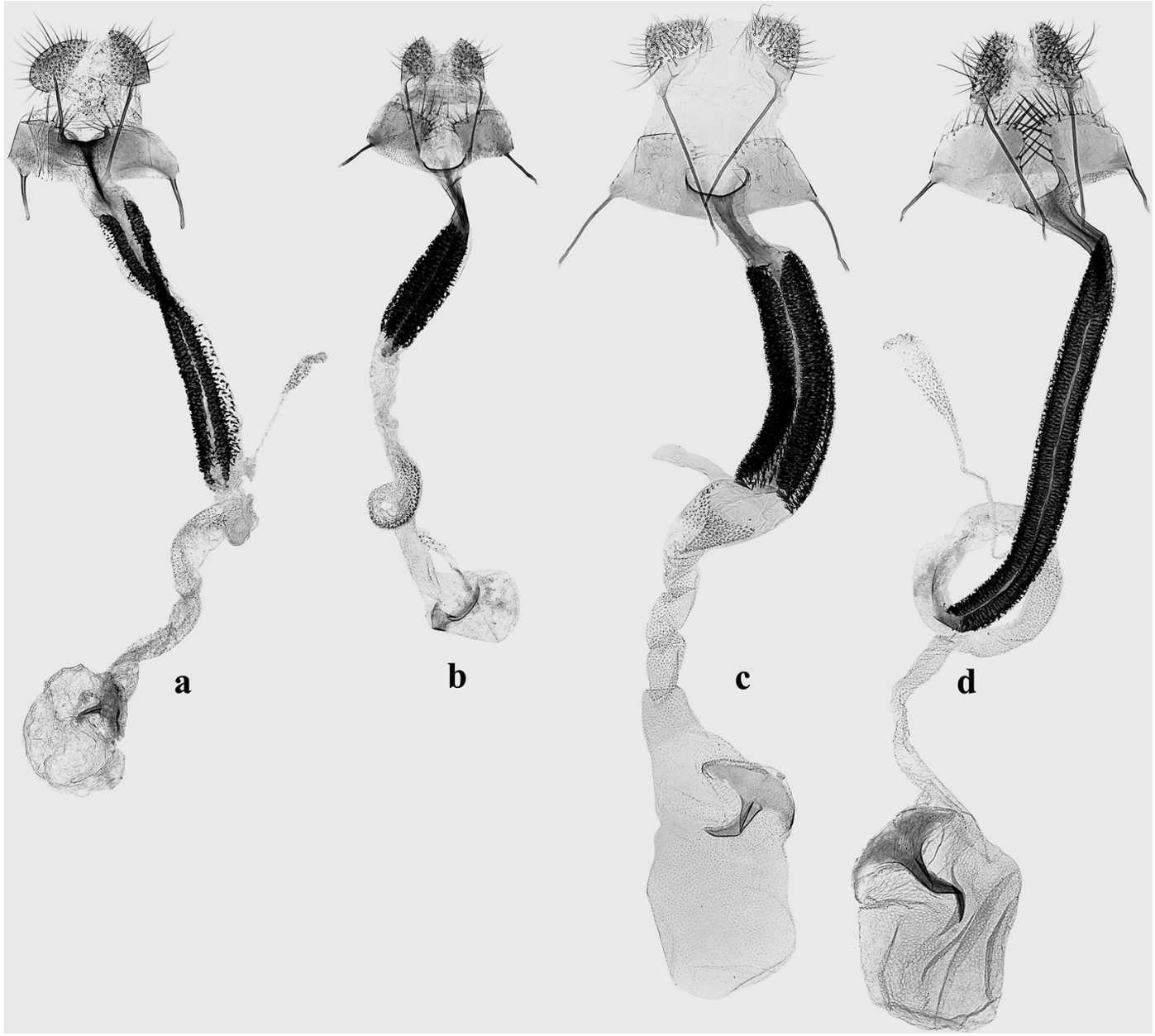

Fig. 3. Female genitalia of four related species of Coleophora. - a. Coleophora sirella sp. n., paratype (GP 4679 J. Tabell). - b. Coleophora juncicolella, Finland, Hartola (GP 4516 J. Tabell). - c. Coleophora murinella, Finland, Hartola (GP 629 J. Tabell). - d. Coleophora glitzella, Finland, Hartola (GP 4566 J. Tabell).

Paavola leg. \& coll.; Finland, EP: Seinäjoki Karvasuo YKJ 6954:292, 15.VI.2012 2 ô (DNA sample 23201 Lepid Phyl) Marko, Nestori \& Anttoni Mutanen leg., coll. M. \& T. Mutanen.

Diagnosis. Coleophora sirella Tabell \& Mutanen, sp. n. is a small species with unicolorous pale brown forewings. It is slightly larger than the smallest North European Coleophora species, C. juncicolella, that feeds on Calluna vulgaris and Erica (Ericaceae), but markedly smaller than the other externally similar species $C$. glitzella and C. murinella, which feed on Vaccinium vitis-idaea L. (Ericaceae). The new taxon may also be confused with $C$. sibiricella Falkovitsh, 1972, a species living on Larix
(Pinaceae), and worn specimens of $C$. antennariella Herrich-Schäffer, 1861, living on Luzula pilosa (L.) Willd. (Juncaceae). The forewing of $C$. sirella $\mathbf{s p . n . ~ ( F i g . ~ 1 ) ~ i s ~ l a n c e o l a t e ~ w i t h ~}$ long costal apical fringes. In fresh specimens, a few orange-brown scales are present at fold, unlike in the allied species (colour drawings are presented in Emmet 1996). The male genitalia of $C$. sirella $\mathbf{s p .}$. (Fig. 2a) are easy to separate from those of the other coleophorids with unstriped forewings by its dorsally narrow and extremely strongly sclerotized phallotheca. In $C$. juncicolella (Fig. 2b), it is more wedge-shaped and more or less evenly chitinized. In both $C$. murinella (Fig. 2c) and C. glitzella (Fig. 2d), the 
Fig. 4. Maximum likelihood tree of an assortment of European unicolorous Coleophora species, based on sequences of $\mathrm{COI}$ gene. Node bootstrap support values are indicated by the nodes. Sample size for each species is indicated in parentheses after species name. The height of terminal triangles is proportional to sample size, the depth to degree of intraspecific variation.
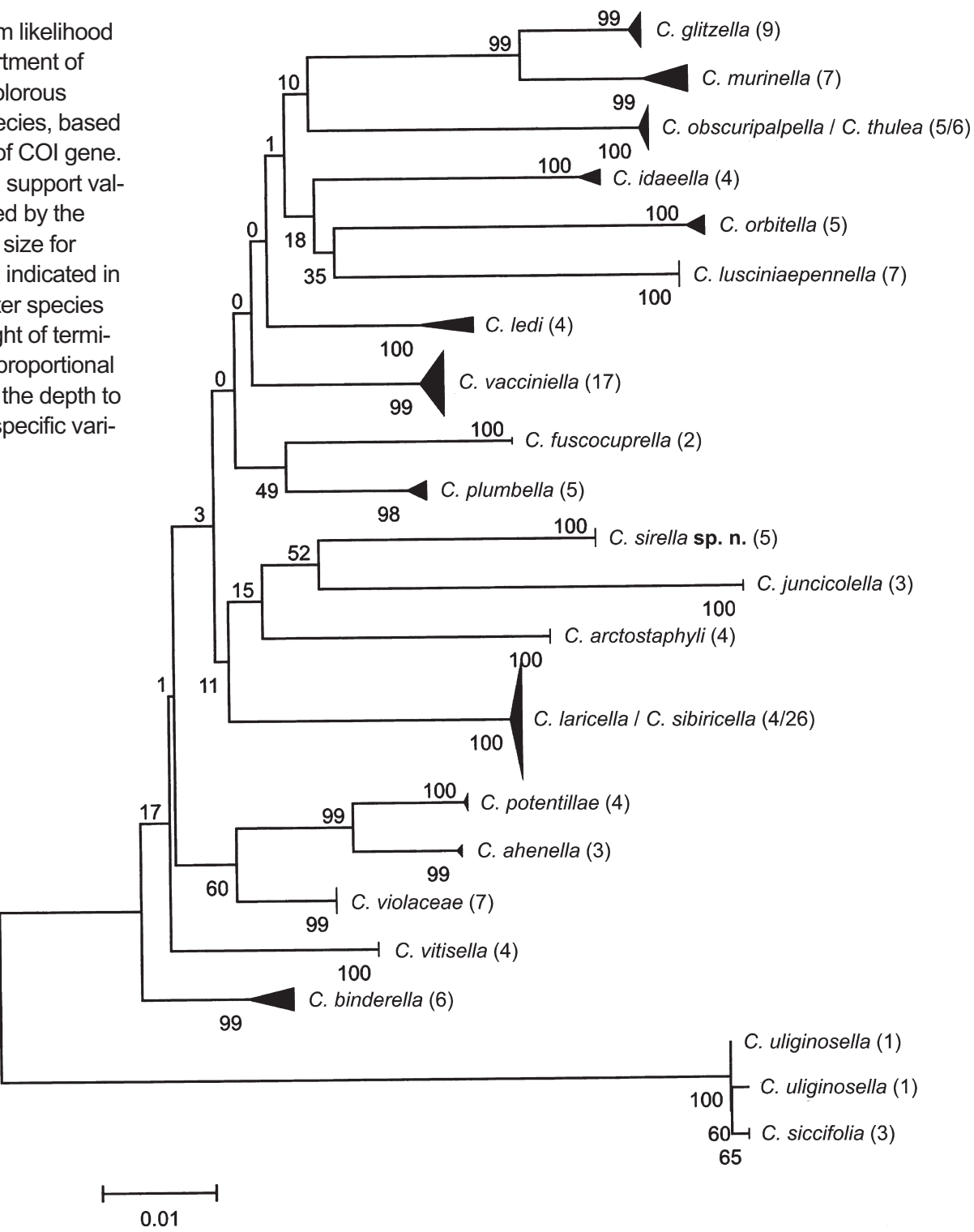

phallotheca is arched too, but it is dorsally weekly sclerotized. In C. sibiricella and C. antennariella, the phallotheca consists of two strongly chitinized rods. The female genitalia of $C$. sirella $\mathbf{s p}$. n. (Fig. 3a) are characterized by chaliced antrum, shape and position of ostium in the distal margin of the sterigma, and by a long spinulate section of ductus bursae. In C. juncicolella (Fig. 3b) and $C$. murinella (Fig. 3c), the spinulate section is much shorter, and ostium is situated at the anterior margin of sterigma, as also in C. glitzella (Fig. 3d). In $C$. sibiricella, the shape of sterigma and a large signum are separating details from $C$. sirella $\mathbf{s p .}$ n. For comparison of the genitalia, see also Razowski (1990) and Emmet (1996).

Molecular diagnosis (Fig. 4). A full length of $658 \mathrm{bp}$ barcode fragments of COI gene was obtained from three $C$. sirella $\mathbf{s p .}$ n. specimens. They were compared to all available corresponding sequences of the Palaearctic and Nearctic Coleophora species. Concerning European species, the DNA barcode analysis (only specimens with full barcode sequence considered) shows that the $\mathrm{K} 2 \mathrm{P}$ distance to the nearest neighbour, 
Table 1. Interspecific divergences (658 bp) of Coleophora sirella sp. $\mathbf{n}$. and related species, based on the analysis of $\mathrm{COI}$ gene. The maximum intraspecific variations are marked in bold.

\begin{tabular}{lcccc}
\hline & C. sirella sp. $\mathbf{n}$. & C. glitzella & C. juncicolella & C. murinella \\
\hline C. sirella sp. $\mathbf{n} .(n=3)$ & $\mathbf{0}$ & 5.91 & 6.24 & 6.25 \\
C. glitzella $(n=9)$ & & $\mathbf{0 . 3 1}$ & 6.93 & 2.19 \\
C. juncicolella $(n=3)$ & & & $\mathbf{0}$ & 7.10 \\
C. murinella $(n=7)$ & & & & $\mathbf{0 . 7 7}$ \\
\hline
\end{tabular}

morphologically nonsimilar C. fuscocuprella Herrich-Schäffer, 1854, is $4.69 \%$. The nearest neighbour to $C$. sirella sp. n. is, however, the Nearctic C. glaucella Walsingham, 1882 (feeds on Arctostaphylos glauca Lindl (Ericaceae)), with the minimum divergence of $4.59 \%$ to $C$. sirella sp. n. The divergences between $C$. sirella sp. n. and three morphologically similar species, namely $C$. juncicolella, $C$. glitzella and $C$. murinella, are $5.91 \%-6.25 \%$ (Table 1). Each taxon displays a low to moderate intraspecific variation, the maximum distance being $0.0 \%$ in C. juncicolella $(n=3)$ and $C$. sirella $\mathbf{s p .} \mathbf{n} .(n=3)$, $0.31 \%$ in $C$. glitzella $(n=9)$ and $0.77 \%$ in $C$. murinella $(n=7)$. The results indicate that $C$. sirella $\mathbf{~ s p . ~ n . ~ c a n ~ u n a m b i g u o u s l y ~ b e ~ d i s t i n g u i s h e d ~}$ from the other species also by the DNA barcodes.

Description. Imago (Fig. 1): Wingspan $\hat{\sigma}$ 9.0-10.5 mm, q 7.8-8.3 mm. Head and thorax pale brown, postocular scales whitish. Antenna pale grey, annulated with brown, scape concolorous with head. Labial palpus pale brown, darker apically. Forewing pale brown, suffused with light ochre scales, especially along fold, fringe concolorous with ground colour, costal fringe long, basally paler. Hindwing and fringe pale greyish brown. Abdomen pale greyish brown, tergal patches (Fig. $5 \mathrm{a}-\mathrm{b}, 3^{\text {rd }}$ segment) $2 \times$ longer than wide, covered with about 30 small conical spines.

Male genitalia (Fig. 2a): Gnathos knob transversely oval, arms rather long. Tegumen broad, almost parallel-sided, pedunculi very short. Cucullus short, distal half extended beyond sacculus. Valvula twice as broad as cucullus, ventral margin broadly rounded, surface covered with short bristles. Transtilla straight, narrow, gradually tapered towards apex. Sacculus well sclerotized; ventral margin rounded, ending in sharp angle; dorsal margin straight or lightly convex. Phallotheca dorsally narrowly and darkly sclerotized, arched tube. In vesica one cluster of several small, spiniform cornuti.

Female genitalia (Fig. 3a): Papillae anales broad, outer margins rounded. Anterior apophyses as long as sterigma, posterior apophyses twice longer than anterior apophyses. Sterigma transverse, $3.5 \times$ as wide as long, caudal margin slightly rounded, with a row of 6-7 long bristles on each side of ostium. Ostium broadly U-

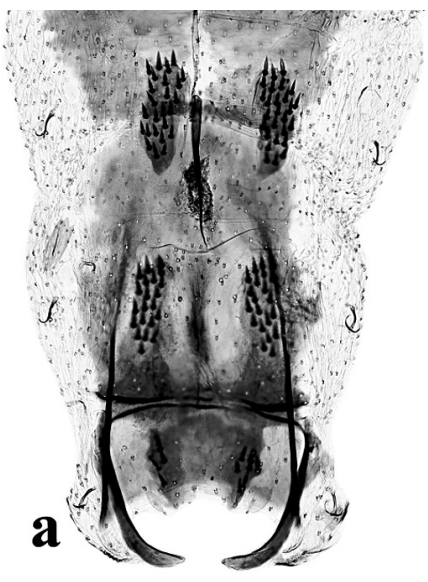

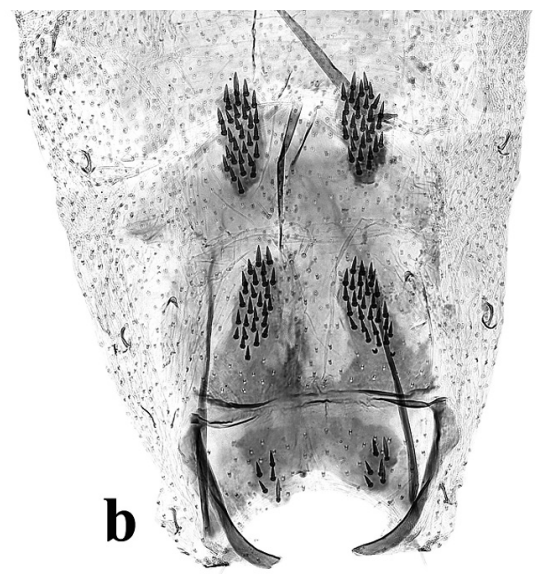

Fig. 5. Abdomens of Coleophora sirella sp. n. - a. Male. - b. Female. 
Fig. 6. Larval case of Coleophora sirella sp. $n$.

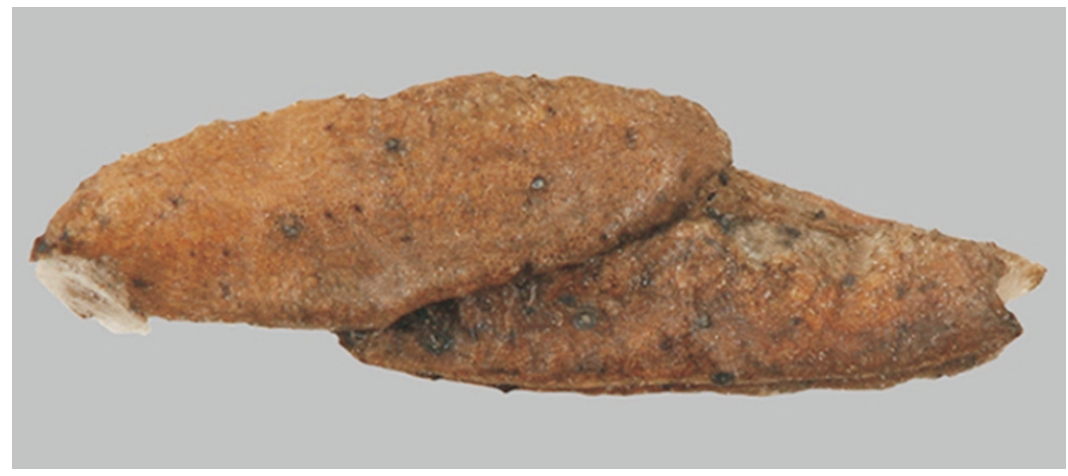

shaped, situated in posterior third of sterigma, without marginal setae. Posterior part of colliculum chaliced, strongly chitinized, anterior part swollen, almost transparent. Spinulate section of ductus bursae about $7 \times$ longer than sterigma, twisted at posterior quarter, anterior section with one coil. Corpus bursae oval. Signum relatively large, base broad, spine slender, almost straight.

Biology. The life cycle of $C$. sirella $\mathbf{s p .} \mathbf{n}$. is incompletely known. The larva probably feeds exclusively on the leaves of Empetrum nigrum and makes the case (Fig. 6) from an empty mined leaf, which it cuts off from the host plant. Subsequently it widens the case by adding another piece of a hollow leaf to the anterior part of its case. The larva supposedly overwinters twice, the latter time as mature. Despite industrious searching of larvae by several collectors, only a few larvae have been found so far, the rearing resulting in one adult and one parasite. Males are active in the morning, at sunrise between 05.00 and 07.30 (summer time), flying above twigs of Empetrum and Calluna. The female adults appear less mobile and prefer to sit at tips of bog shrubs making only small spurts instead of flying longer distances. Most females have been caught in the afternoon, between 16.00-18.00 (summer time). The flight period is about one week, from the beginning of June (southern Finland) to the beginning of July (northern Finland). The habitats are open Empetrum bogs and sandy moors surrounded by bogs.

Distribution. The species is so far known only from Finland, where it is widely but locally distributed over most of the country, excluding northernmost regions. Probably $C$. sirella $\mathbf{s p .}$. has a wider, at least Palaearctic, distribution range, judging from the wide distribution and prevalence of its host plant, E. nigrum. Supposedly, the short flying period, early flying time and inconspicuous appearance of the adult have hampered the discovery of the species until now.

Etymology. The species name is derived from the first letters of the name Reijo Siloaho, the Finnish lepidopterist who has collected the majority of the type material.

\section{Discussion}

As we have sequence data from only a single mitochondrial gene, the phylogenetic position of $C$. sirella sp. n. remains uncertain. Based on the DNA barcode based phylogeny, its sister species is $C$. juncicolella. This appears a likely scenario, because these species also share similar external morphology, relatively similar genitalia, and both feed on Ericaceae. A sister species to them, although poorly supported, is C. arctostaphyli Meder, 1934 that also feeds on Ericaceae and is morphologically similar. The monophyly of Coleophora feeding on Ericaceae appears possible, although in our tree, a few species were nested within the complex. Our result is largely consistent with the phylogeny of Bauer et al. (2012), which is based on COI and wingless genes. However, their analysis lacked $C$. sirella sp. n. and $C$. arctostaphyli. They found strong support for the monophyly of the $C$. vacciniella complex, but consistent with our results, they did not recover Ericaceae feeding species within it forming a monophylum. Interestingly, C. vacciniella Herrich-Schäffer, 1861, a species usually living on Ericaceae, has unusually broad diet and 
is known to feed also e.g. on Salix (Salicaceae), Spiraea and Rubus chamaemorus L. (Rosaceae), Myrica gale L. (Myricaceae) and Betula (Betulaceae).

Acknowledgements. We thank Kari Nupponen and Lauri Kaila for commenting the manuscript, and the collectors of the type specimens for providing us material and different kind of information. We thank the Kone Foundation, Finnish Cultural Foundation and the Academy of Finland for support in barcoding through the Finnish Barcode of Life initiative. We are also grateful to the staff of the Canadian Centre for DNA barcoding for sequencing the samples and continuous help in management our BOLD records.

\section{References}

Bauer, F., Stübner, A., Neinhuis, C. \& Nuss, M. 2012: Molecular phylogeny, larval case architecture, hostplant associations and classification of European Coleophoridae (Lepidoptera). — Zoologica Scripta 41: 248265. doi: https://doi.org/10.1111/j.1463-6409.2012. 00532.x
deWaard, J. R., Ivanova, N. V., Hajibabaei, M. \& Hebert, P. D. N. 2008: Assembling DNA Barcodes: Analytical Protocols. - In: Cristofre, M. (ed.). Methods in Molecular Biology: Environmental Genetics: 275-293. Humana Press Inc., Totowa, 362 pp. doi: https:// doi.org/10.1007/978-1-59745-548-0_15

Emmet, A. M. (ed.) 1996: The Moths and Butterflies of Great Britain and Ireland. Volume 3. [Yponomeutidae-Elachistidae]. — Harley Books, Colchester. 452 pp.

Johansson, R. 1967: Coleophora thulea n. sp. (Lep. Coleophoridae). - Opuscula Entomologica 32: 135-138.

Kanerva, N. 1941: Mitteilungen über die Coleophoridae (Lep.) Finnlands. I-II. - Suomen Hyönteistieteellinen Aikakauskirja 7: 117-127.

Kumar, S. \& Tamura K. 2016: MEGA7: Molecular Evolutionary Genetics Analysis Version 7.0 for Bigger Datasets. - Molecular Biology and Evolution 33: 1870 1874. doi: https://doi.org/10.1093/molbev/msw054

Razowski, J. 1990: Motyle (Lepidoptera) Polski, Czesc XVI - Coleophoridae. - Monografie Fauny Polski 18. Polska Akademia Nauk, Warszawa, Kraków. 270 pp. +1 pl.

Robinson, G. 1976: The preparation of slides of Lepidoptera genitalia with special reference to the Microlepidoptera. — Entomologist's Gazette 27: 127-132. 